\title{
Spontaneous Streptococcus mitis Meningitis in a Patient with Liver Cirrhosis: A Case Report and Literature Review
}

\author{
Andrew Villion1, Michael Lishner ${ }^{1,2}$, Michal Chowers' ${ }^{1,3}$, Sharon Reisfeld ${ }^{1,2 *}$ \\ ${ }^{1}$ Sackler School of Medicine, Tel Aviv University, Tel Aviv, Israel \\ ${ }^{2}$ Department of Medicine A, Meir Medical Center, Kfar Saba, Israel \\ ${ }^{3}$ Infectious Diseases Unit, Meir Medical Center, Kfar Saba, Israel \\ Email: sharon.reisseld@clalit.org.il
}

Received 18 May 2014; revised 15 June 2014; accepted 11 July 2014

Copyright (C) 2014 by authors and Scientific Research Publishing Inc.

This work is licensed under the Creative Commons Attribution International License (CC BY). http://creativecommons.org/licenses/by/4.0/

c) (i) Open Access

\begin{abstract}
Streptococcus mitis is a component of the normal oropharynx, skin, gastrointestinal system, and genital tract florae. It is generally considered as a relatively benign bacterium. We present a case of spontaneous Streptococcus mitis meningitis in a patient with liver cirrhosis and no known risk factors for invasive infectious diseases.
\end{abstract}

\section{Keywords}

Streptococcus mitis, Cirrhosis, Meningitis

\section{Introduction}

Streptococcus mitis (S. mitis) is an alpha-hemolytic species belonging to the family of viridans streptococci. $S$. mitis is a component of the normal oropharynx, skin, gastrointestinal system, and genital tract floras [1].

Patients with cirrhosis who have not developed major complications are classified as having compensated cirrhosis.

Patients who have developed complications of cirrhosis, such as variceal hemorrhage, ascites, spontaneous bacterial peritonitis, hepatocellular carcinoma, hepatorenal syndrome, or hepatopulmonary syndrome are considered to have decompensated cirrhosis and have a worse prognosis than those with compensated cirrhosis [2]. A few cases of $S$. mitis meningitis were described in the literature; most of them were associated with risk factors like invasive procedures or a recent upper respiratory tract infection [3] [4]. We present a rare case of spontane-

${ }^{*}$ Corresponding author.

How to cite this paper: Villion, A., Lishner, M., Chowers, M. and Reisfeld, S. (2014) Spontaneous Streptococcus mitis Meningitis in a Patient with Liver Cirrhosis: A Case Report and Literature Review. Case Reports in Clinical Medicine, 3, 398-401. http://dx.doi.org/10.4236/crcm.2014.37088 
ous S. mitis meningitis in a patient with liver cirrhosis and no other risk factors for such an invasive infection.

\section{Case Report}

A 58-year-old male presented with complaints of headache, photophobia, and vomiting that started two days prior to admission and worsened on the admission day. The patient had no fever at home or signs of altered mental status. He had no history of invasive procedures or upper respiratory tract infection. His medical history included Type II diabetes mellitus, controlled with oral medications with current glycated hemoglobin level of $6 \%$, cryptogenic liver cirrhosis with thrombocytopenia, splenomegaly, elevated liver enzymes (5-fold increase) and negative serological and autoimmune workup. On physical examination, temperature was $37^{\circ} \mathrm{C}\left(98.6^{\circ} \mathrm{F}\right)$. He appeared somnolent, with nuchal rigidity and no focal neurological deficits. There was no rash or any skin lesions. The rest of the physical examination was normal. Noncontrast head computed tomography scan did not reveal signs of hemorrhage or increased intracranial pressure. Laboratory values are shown in Table 1. Lumbar puncture was performed and yielded turbid cerebrospinal fluid (CSF) with xantochromia. CSF results showed white blood cell count of 5500 cells/ $\mu$ l with $96 \%$ segmented neutrophils, red blood cell count of 1300 cells/ $\mu$ l with normal morphology, glucose level of $2 \mathrm{mg} / \mathrm{dl}$ and protein level $703 \mathrm{mg} / \mathrm{dl}$ (normal range 15 - $50 \mathrm{mg} / \mathrm{dl}$ ). Gram positive diplococci were seen on gram stain. Empirical treatment with dexamethasone, ampicillin plus ceftriaxone was started.

The patient was admitted to the intensive care unit. Two days after admission blood and CSF cultures were found positive for penicillin sensitive Streptococcus mitis. Therefore, treatment was changed to high dose penicillin. Transesophageal echocardiogram did not reveal vegetations or any other findings suggestive of infective endocarditis.

On the fifth day of admission, the patient developed mild right side hemiparesis. Head magnetic resonance imaging (MRI) revealed high signal intensity in the globus pallidum on T1-weighted images. On the same day, the patient developed massive variceal bleeding that was treated with terlipressin and endoscopic band ligation. Treatment for hepatic encephalopathy was also started. The patient stabilized and continued to improve. He was discharged two weeks after admission with no neurological sequelae. Unfortunately the patient was lost to follow up and we have no information about his current condition.

Table 1. Laboratory data at admission.

\begin{tabular}{|c|c|c|}
\hline Component & Patient Value & Normal Value \\
\hline White blood cells & $13.93 \mathrm{Kc} / \mu \mathrm{l}$ & $4.8-10.8 \mathrm{Kc} / \mu \mathrm{l}$ \\
\hline Hemoglobin & $15.00 \mathrm{~g} / \mathrm{dl}$ & $13.5-17.5 \mathrm{~g} / \mathrm{dl}$ \\
\hline Platelets & $85 \mathrm{Kc} / \mu \mathrm{l}$ & $150-450 \mathrm{Kc} / \mu \mathrm{l}$ \\
\hline Glucose & $162 \mathrm{mg} / \mathrm{dl}$ & $70-100 \mathrm{mg} / \mathrm{dl}$ \\
\hline Sodium & $137 \mathrm{mEq} / \mathrm{L}$ & $135-145 \mathrm{mEq} / \mathrm{L}$ \\
\hline Potassium & $3.3 \mathrm{mEq} / \mathrm{L}$ & $3.5-5.1 \mathrm{mEq} / \mathrm{L}$ \\
\hline Aspartate aminotransferase & $50 \mathrm{U} / \mathrm{L}$ & $0-35 \mathrm{U} / \mathrm{L}$ \\
\hline Alanine transaminase & $30 \mathrm{U} / \mathrm{L}$ & $0-45 \mathrm{U} / \mathrm{L}$ \\
\hline Gammaglutamyl transpeptidase & $138 \mathrm{U} / \mathrm{L}$ & 7 - $49 \mathrm{U} / \mathrm{L}$ \\
\hline Total bilirubin & $2.8 \mathrm{mg} / \mathrm{dl}$ & $0.2-1.5 \mathrm{mg} / \mathrm{dl}$ \\
\hline Albumin & $3.4 \mathrm{gr} / \mathrm{dl}$ & $3.5-5.5 \mathrm{gr} / \mathrm{dl}$ \\
\hline $\mathrm{C}$ reactive protein & $5.01 \mathrm{mg} / \mathrm{dl}$ & $0.00-0.5 \mathrm{mg} / \mathrm{dl}$ \\
\hline International normalized ratio & 1.16 & \\
\hline Creatinine & $0.9 \mathrm{mg} / \mathrm{dl}$ & $0.5-1.2 \mathrm{mg} / \mathrm{dl}$ \\
\hline Urea & $44 \mathrm{mg} / \mathrm{dl}$ & $10-50 \mathrm{mg} / \mathrm{dl}$ \\
\hline
\end{tabular}




\section{Discussion}

Streptococcus mitis (S. mitis) is an alpha-hemolytic species belonging to the family of viridans streptococci. S. mitis is a component of the normal oropharynx, skin, gastrointestinal system, and genital tract floras [1], and has generally been considered a relatively benign bacterium. Nevertheless, S. mitis can cause a range of invasive diseases in humans. Endocarditis caused by $S$. mitis was reported both in adult and pediatric patients [5]. Liver, lung and even myocardial abscesses caused by $S$. mitis were described in a number of case reports in recent years [6]-[9]. S. mitis is an important and underestimated cause of bacteremia and sepsis in neutropenic patients and in cancer patients receiving chemotherapy [10]-[11].

S. mitis has been reported in conjunction with meningitis, but in the majority of the cases, patients had previously undergone invasive procedures such as spinal anesthesia [3] [4]. A case of spontaneous S. mitis meningitis was reported in an adult patient with a history of alcoholism, without chronic liver disease, who also had very poor oral hygiene and maxillary sinusitis [12].

Our patient was diagnosed with S. mitis meningitis; therefore he was evaluated for endocarditis by transesophageal echocardiogram that was negative. The antibiotic treatment was changed to penicillin and gentamycin according to endocarditis guidelines since there are no specific guidelines for S. mitis meningitis [13]. The patient completed 2 weeks of antibiotic treatment as recommended in cases of highly susceptibe bacteria as in our case.

To the best of our knowledge, this is the first case of spontaneous $S$. mitis meningitis in an adult with no risk factors for such an invasive infection, like poor oral hygiene, recent invasive procedures, a recent upper respiratory infection or a history of alcoholism.

Chronic liver disease and especially liver cirrhosis is considered an immunocompromised state that leads to a variety of infections [14]. The patient reported in our case had decompensated cirrhosis and most probably this was the only risk factor for such an invasive infection from a usually benign bacterium.

We are not aware of any reported cases of meningitis caused by S. mitis in cirrhotic patients.

\section{Conclusions}

We described herein, the first case of spontaneous Streptococcus mitis meningitis in a patient with liver cirrhosis and no known risk factors for such an invasive disease.

We emphasize the need to broaden the differential diagnosis of cirrhotic patients with altered mental status. It is important to remember that they are prone to infections from avirulent pathogens due to their liver disease and impaired immune state, including uncommon central nervous system infections similar to that presented here.

\section{References}

[1] Patterson, M.J. (1996) Streptococcus Pyodenes, Other Streptococci, and Enterococcus. In: Baron, S., Ed., Streptococcus, Medical Microbiology, Chapter 13, 4th Edition, University of Texas Medical Branch at Galveston, Galveston.

[2] Goldberg, E. and Chopra, S. (2014) Cirrhosis in Adults: Overview of Complications, General Management, and Prognosis. In: Post, T.W., Ed., UpToDate, Waltham.

[3] Janssen, M. (1996) Alpha-Hemolytic Streptococci: A Major Pathogen of Iatrogenic Meningitis Following Lumbar Puncture. Case Reports and a Review of the Literature. Infection, 24, 29-33. http://dx.doi.org/10.1007/BF01780647

[4] Villevieille, T., Vincenti-Rouquette, I., Petitjeans, F., et al. (2000) Streptococcus mitis-Induced Meningitis after Spinal Anesthesia. Anesthesia Analgesia, 90, 500-501.

[5] Rapeport, K.B., Giron, J.A. and Rosner, F. (1986) Streptococcus mitis Endocarditis: Report of 17 Cases. Archives of Internal Medicine, 146, 2361-2363.

[6] Sarthy, J. and DiBardino, D. (2013) Pyogenic Liver Abscess Caused by Streptococcus mitis. The Lancet Infectious Diseases, 13, 822. http://dx.doi.org/10.1016/S1473-3099(13)70166-X

[7] Takayanagi, N., Kagiyama, N., Ishiguro, T., Tokunaga, D. and Sugita Y. (2010) Etiology and Outcome of CommunityAcquired Lung Abscess. Respiration, 80, 98-105. http://dx.doi.org/10.1159/000312404

[8] Basil, A., Schoch, P.E. and Cunha, B.A. (2012) Viridans Streptococcal Biosynthetic Aortic Prosthetic Valve Endocarditis (PVE) Complicated by Complete Heart Block and Paravalvular Abscess. Heart \& Lung: The Journal of Acute and Critical Care, 41, 610-612. http://dx.doi.org/10.1016/j.hrtlng.2012.05.002

[9] Lo, R., Rae, J., Noack, D., Curnutte, J.T. and Avila, P.C. (2005) Recurrent Streptococcal Hepatic Abscesses in a 46-Year-Old Woman. Annals of Allergy, Asthma Immunology, 95, 325-329. 
http://dx.doi.org/10.1016/S1081-1206(10)61149-0

[10] Marron, A., Carratala, J., Gonzalez-Barca, E., Fernandez-Sevilla, A., Alcaide, F. and Gudiol, F. (2010) Serious Complications of Bacteremia Caused by Viridans Streptococci in Neutropenic Patients with Cancer. Clinical Infectious Diseases, 31, 1126-1130. http://dx.doi.org/10.1086/317460

[11] Ahmed, R., Hassall, T., Morland, B. and Gray, J. (2003) Viridans Streptococcus Bacteremia in Children on Chemotherapy for Cancer: An Underestimated Problem. Journal of Pediatric Hematology/Oncology, 20, 439-444. http://dx.doi.org/10.1080/08880010390220144

[12] Kutlu, S.S., Sacar, S., Cevahir, N. and Turgut, H. (2008) Community-Acquired Streptococcus mitis Meningitis: A Case Report. International Journal of Infectious Diseases, 12, 107-109. http://dx.doi.org/10.1016/j.ijid.2008.01.003

[13] Baddour, L.M., Wilson, W.R., Bayer, A.S., Fowler Jr., V.G., Bolger, A.F., Levison, M.E., Ferrieri, P., Gerber, M.A., Tani, L.Y., Gewitz, M.H., Tong, D.C., Steckelberg, J.M., Baltimore, R.S., Shulman, S.T., Burns, J.C., Falace, D.A., Newburger, J.W., Pallasch, T.J., Takahashi, M. and Taubert, K.A. (2005) Infective Endocarditis: Diagnosis, Antimicrobial Therapy, and Management of Complications; A Statement for Healthcare Professionals from the Committee on Rheumatic Fever, Endocarditis, and Kawasaki Disease, Council on Cardiovascular Disease in the Young, and the Councils on Clinical Cardiology, Stroke, and Cardiovascular Surgery and Anesthesia, American Heart Association. Circulation, 111, e394-e433. http://dx.doi.org/10.1161/CIRCULATIONAHA.105.165564

[14] Tandon, P. and Garcia-Tsao, G. (2008) Bacterial Infections, Sepsis, and Multiorgan Failure in Cirrhosis. Seminars in Liver Disease, 28, 26-42. http://dx.doi.org/10.1055/s-2008-1040319 
Scientific Research Publishing (SCIRP) is one of the largest Open Access journal publishers. It is currently publishing more than 200 open access, online, peer-reviewed journals covering a wide range of academic disciplines. SCIRP serves the worldwide academic communities and contributes to the progress and application of science with its publication.

Other selected journals from SCIRP are listed as below. Submit your manuscript to us via either submit@scirp.org or Online Submission Portal.
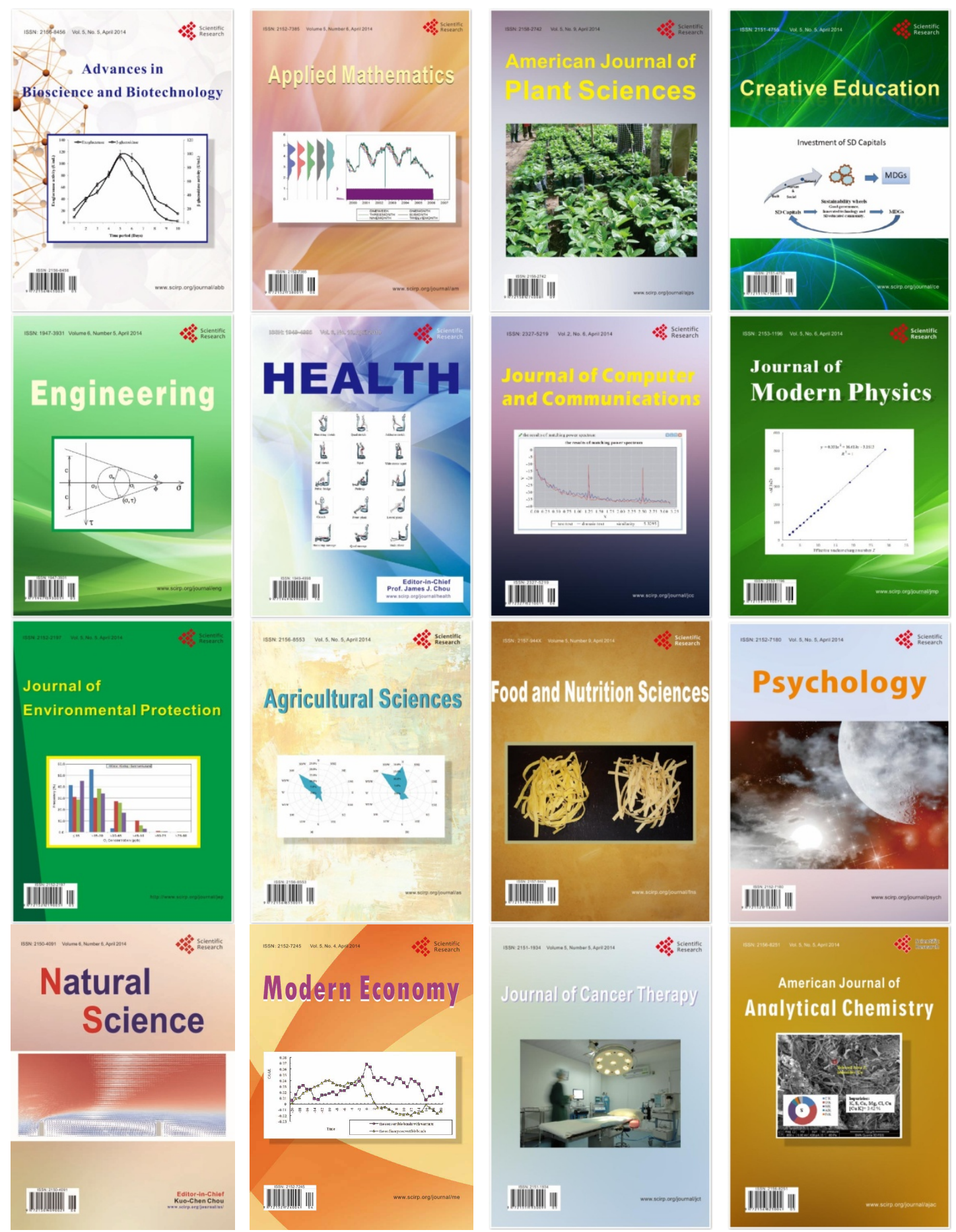